\title{
A systematic review on Multisystem Inflammatory Syndrome in Children (MIS-C) with COVID-19: Development of a scoring system for clinical diagnosis
}

Suchitra V Surve $^{1^{*}}$, Shaini Joseph ${ }^{2}$, Rahul K Gajbhiye ${ }^{1}$, Smita D Mahale ${ }^{3}$, Deepak N Modi $^{4}$

${ }^{1}$ Department of Clinical Research, ${ }^{2}$ Department of Genetics, ${ }^{3}$ ICMR Emeritus Scientist, ${ }^{4}$ Department of Molecular and Cellular Biology Laboratory, ICMR- National Institute for Research in Reproductive Health, J M Street, Parel, Mumbai 400012, INDIA.

\section{"Corresponding author:}

Dr.Suchitra V Surve

Scientist C

Department of Clinical Research

ICMR- National Institute for Research in Reproductive Health

J M Street, Parel, Mumbai 400012, INDIA

Telephone: +9122 24192029

Email : dr.suchi172@gmail.com 
medRxiv preprint doi: https://doi.org/10.1101/2021.04.23.21255879; this version posted April 25, 2021 . The copyright holder for this preprint (which was not certified by peer review) is the author/funder, who has granted medRxiv a license to display the preprint in perpetuity.

All rights reserved. No reuse allowed without permission.

MIS-C and COVID-19

\section{Abstract}

\section{Background}

There is growing evidence of Multisystem Inflammatory Syndrome in Children (MIS-C) resembling Kawasaki disease in children infected with SARS-CoV-2. The review was undertaken to evaluate the case definition, the spectrum of clinical presentations and current management practices in children with COVID-19 presenting with or without MIS-C.

\section{Methods}

The individual patient data from 119 studies accounting for 333 children were analyzed. We devised a scoring system as per WHO criteria to classify the patients as MIS-C or without MIS-C. A score of 3 was given for the presence of fever (>24h) and a score of 1 for labconfirmed diagnosis of SARS-CoV-2. Additionally, a score of 1 was given for a) rash or conjunctivitis or muco-cutaneous inflammation signs, b) hypotension or shock, c) diarrhea, vomiting or abdominal pain, d) features of myocardial dysfunction as determined by abnormal eco-cardiography or elevated Troponin or N-terminal pro B-type Natriuretic Peptide (NT-proBNP), e) evidence of coagulopathy as evidenced by elevated levels of prothrombin time PT, partial thromboplastin time PTT or D-dimer, f) laboratory evidence of inflammation as determined by elevated erythrocyte sedimentation rate (ESR) or C-reactive protein (CRP) or procalcitonin. A negative score of (-3) was given when there was a diagnosis of sepsis, staphylococcal or streptococcal shock syndrome. Based on these criteria, a minimum score of 6 was essential to classify the child as MIS-C.

\section{Results}

Based on this score, $18 \%$ (52/289) of cases were identified to be MIS-C. A greater proportion of children with MIS-C had cardiac involvement (MIS-C $80 \%$ vs Non-MIS-C 20\%) and gastrointestinal involvement (MIS-C $71 \%$ vs Non-MIS-C 12\%). Lymphopenia was commonly reported in MIS-C (MIS-C 54.2\% vs Non-MIS-C 29.7\%). In addition to routine inflammatory markers, significantly greater proportion of children with MIS-C had elevated Ferritin, LDH, Fibrinogen and IL-6. Children with MIS-C were less likely to have respiratory symptoms like cough (MIS-C 25\% vs Non-MIS-C 75\%) and rhinorrhea (MIS-C 4\% vs NonMIS-C 22.8\%). A greater proportion of children with MIS-C required intensive care and aggressive treatment; and mortality rates were also higher in MIS-C group (MIS-C 10\% vs Non-MIS-C $1 \%$ ). 
medRxiv preprint doi: https://doi.org/10.1101/2021.04.23.21255879; this version posted April 25, 2021 . The copyright holder for this preprint (which was not certified by peer review) is the author/funder, who has granted medRxiv a license to display the preprint in perpetuity. All rights reserved. No reuse allowed without permission.

\section{MIS-C and COVID-19}

\section{Conclusion}

The children with COVID-19 having cardiac and/or gastrointestinal involvement are more likely to develop MIS-C. The children with MIS-C have higher mortality rates. The scoring system developed herein will aid clinicians in patient diagnosis and timely management.

Keywords: Children, COVID-19, Hyperinflammatory syndrome, Kawasaki disease, Multisystem involvement, SARS-COV-2. 
medRxiv preprint doi: https://doi.org/10.1101/2021.04.23.21255879; this version posted April 25, 2021. The copyright holder for this preprint (which was not certified by peer review) is the author/funder, who has granted medRxiv a license to display the preprint in perpetuity.

All rights reserved. No reuse allowed without permission.

MIS-C and COVID-19

\section{Introduction}

Children account for 1-5\% of diagnosed novel coronavirus disease of 2019 (COVID-19) caused by severe acute respiratory syndrome coronavirus (SARS-CoV-2) ${ }^{113}$. Despite the initial assumption that children seem to be less severely affected by COVID-19 ${ }^{3}$, there is growing evidence of diverse and unusual presentations of SARS-CoV-2 infections in the pediatric population. This is posing a huge challenge in the clinical management of children with COVID-19 4 .

Kawasaki disease $(\mathrm{KD})$ is an acute febrile systemic vasculitis of unknown etiology occurring predominantly under the age of 5 years with a probable link with viral or bacterial illness ${ }^{6 i ̈} 10$. It is hypothesized that an unknown trigger (most likely an infectious agent) leads to an exaggerated inflammatory response manifesting as KD. Previously, coronavirus infection has been reported to be associated with $\mathrm{KD}^{10}$. Case reports from Europe, USA and India have shown hyperinflammatory responses in pediatric COVID-19 which have overlapping features with $\mathrm{KD}^{111115}$. However, whether these manifestations should be considered as a clinical spectrum of COVID-19 or as a result of a secondary infection triggered by SARS-CoV-2 is debatable. Nevertheless, for provisional reporting and surveillance, World Health Organization (WHO) and Center for Disease Control and Prevention (CDC) has categorized this condition as Multisystem Inflammatory Syndrome (MIS-C) related to COVID- 19 in children and adolescents ${ }^{16,17}$.

The case definition proposed by WHO and CDC have notable differences. CDC proposes MIS-C as an individual aged $<21$ years presenting with fever $\geq 38.0^{\circ} \mathrm{C}$ for $\mathrm{O}_{4} 4$ hours, laboratory evidence of inflammation and evidence of clinically severe illness requiring hospitalization with multisystem $(\geq 2)$ organ involvement (cardiac, renal, respiratory, hematologic, gastrointestinal, dermatologic or neurological); AND no alternative plausible diagnoses; AND positive for current or recent SARS-CoV-2 infection by RT-PCR, serology or antigen test; or COVID-19 exposure within the 4 weeks prior to the onset of symptoms. However, WHO case definition differs in terms of age group (includes children and adolescents $<19$ years), duration of fever (> 3days) and two of either rash or bilateral nonpurulent conjunctivitis or muco-cutaneous inflammation signs (oral, hands or feet), hypotension or shock, myocardial dysfunction, pericarditis, valvulitis or coronary abnormalities, evidence of coagulopathy or acute gastrointestinal problems along with elevated markers of inflammation without any evidence of sepsis in presence of COVID-19 
medRxiv preprint doi: https://doi.org/10.1101/2021.04.23.21255879; this version posted April 25, 2021. The copyright holder for this preprint (which was not certified by peer review) is the author/funder, who has granted medRxiv a license to display the preprint in perpetuity.

All rights reserved. No reuse allowed without permission.

MIS-C and COVID-19

(RT-PCR, antigen test or serology positive) or contact with patients with COVID-19. Though the WHO criteria appear to be more specific concerning children, it needs refinement with regards duration of fever, the inclusion of other neurological and renal system involvement. Thus, there is a need to revisit the case definition and classification of MIS-C. Also, the clinical characteristics, the presenting symptoms and the outcome of children with MIS-C and the non-MIS-C needs to be determined.

With increasing numbers of case reports of MIS-C with SARS-COV-2, the available information is being collated systematically to create substantial learning in diagnosing and managing pediatric COVID cases ${ }^{18,19}$. These studies have highlighted that MIS-C is an integral component of pediatric infections with SARS-CoV-2. However, it is increasingly getting evident that the presentation of MIS-C in children appears diverse and there are differences in case definitions across various studies. This makes it harder for pediatricians to accurately define MIS-C patients in their clinical setup and epidemiologists to carry out detailed systematic reviews.

To address this, we carried out a systematic review that aimed at evaluating the case definition, the spectrum of clinical presentations and current management practices in children with COVID-19 presenting with and without MIS-C. The ultimate goal is to evolve a scoring system that would aid clinicians to classify MIS-C in their routine practice and identify the clinical characteristics of MIS-C.

\section{Methods}

A systematic review (PROSPERO ID CRD42020185491) was carried out as per Preferred Reporting Items for Systematic reviews and Meta-analysis (PRISMA) guidelines.

\section{Search Strategy}

The PubMed and Google Scholar literature database, journal databases, preprints servers and specialized resources like COVID-19 Research Database, LitCovid, CNKI database comprising of over 3900 Chinese journals were searched systematically using COVID-19 search terms: "coronavirus", "COVID19", "2019-nCoV", "SARS-CoV-2", "COVID-19", "COVID" together with keywords commonly used to refer to pediatric population: "pediatric", "neonateò, "newborn", "new-born", "infant", "child*", "children". An additional search was also performed to check for articles on the multisystem inflammatory syndrome in children. The snowballing method was also applied to search for missed articles. 
medRxiv preprint doi: https://doi.org/10.1101/2021.04.23.21255879; this version posted April 25, 2021. The copyright holder for this preprint (which was not certified by peer review) is the author/funder, who has granted medRxiv a license to display the preprint in perpetuity. All rights reserved. No reuse allowed without permission.

MIS-C and COVID-19

\section{Study selection and strategy for data extraction and synthesis}

A pre-requisite for precise case definition requires sets of individual data. Since it is possible that early studies on children with COVID-19 may have reported the data but would have missed defining the case as MIS-C or conversely some studies may have over-interpreted the presentations as MIS-C, we chose to redefine the cases using a uniform criterion. Hence, we only included those studies where individual patient data were available as it allowed us to re-classify the patients uniformly.

All articles published between January 1, 2020 and June 1, 2020 were retrieved and filtered to remove duplicate entries. Studies published in other languages were included if translated by google translator. The articles of interest were selected in three steps, firstly based on article title, then article abstract and in the third step the full-text article was assessed. Original studies reporting primary individual patient data younger than 18 years of age and diagnosed with SARS-CoV-2 by laboratory method (PCR or antibody testing) were included. Studies reporting clinical guidelines, consensus documents, clinical trials, reviews, systematic reviews, clinical diagnoses of COVID-19 without laboratory conýrmation were excluded. Primary data was extracted, cross-checked and any discrepancies were resolved.

\section{Development of the scoring system}

To uniformly classify the patients as Multisystem Inflammatory Syndrome in Children (MISC) a scoring system was devised (Table 1). Herein a score of 3 was given for the presence of fever ( $>24 \mathrm{~h}$ ) and a score of 1 for a lab-confirmed diagnosis of SARS-CoV-2. Additionally, a score of 1 was given for a) rash or conjunctivitis or muco-cutaneous inflammation signs, b) hypotension or shock, c) diarrhea, vomiting or abdominal pain, d) features of myocardial dysfunction as determined by abnormal eco-cardiography or by elevated Troponin or Nterminal pro B-type Natriuretic Peptide (NT-proBNP) levels, e) evidence of coagulopathy as evidenced by elevated levels of prothrombin time PT, partial thromboplastin time PTT or Ddimer, f) laboratory evidence of inflammation as determined by elevated erythrocyte sedimentation rate (ESR) or C-reactive protein (CRP) or procalcitonin. A negative score of ( 3) was given when there was a diagnosis of sepsis, staphylococcal or streptococcal shock syndrome. Based on these criteria, a minimum score of 6 was essential to classify the child as MIS-C (Table 1).

\section{Measures}

Pearsonô Chi-square or Fisherôs exact test was applied wherever appropriate and a value of $p$ $<0.05$ was considered as statistically significant. All the statistical analysis was performed using SPSS package version 19.0 (Armonk, NY: IBM Corp). 
medRxiv preprint doi: https://doi.org/10.1101/2021.04.23.21255879; this version posted April 25, 2021. The copyright holder for this preprint (which was not certified by peer review) is the author/funder, who has granted medRxiv a license to display the preprint in perpetuity. All rights reserved. No reuse allowed without permission.

\section{MIS-C and COVID-19}

\section{Results}

After screening and assessment of eligibility (Fig 1), a total of 1211 articles were identified through database searches and snowballing. Of these, 150 studies were found eligible for inclusion and analyzed in the systematic review. Of the 150 studies, 31 had aggregate data and hence were excluded. Finally, 119 studies with individual data were included.

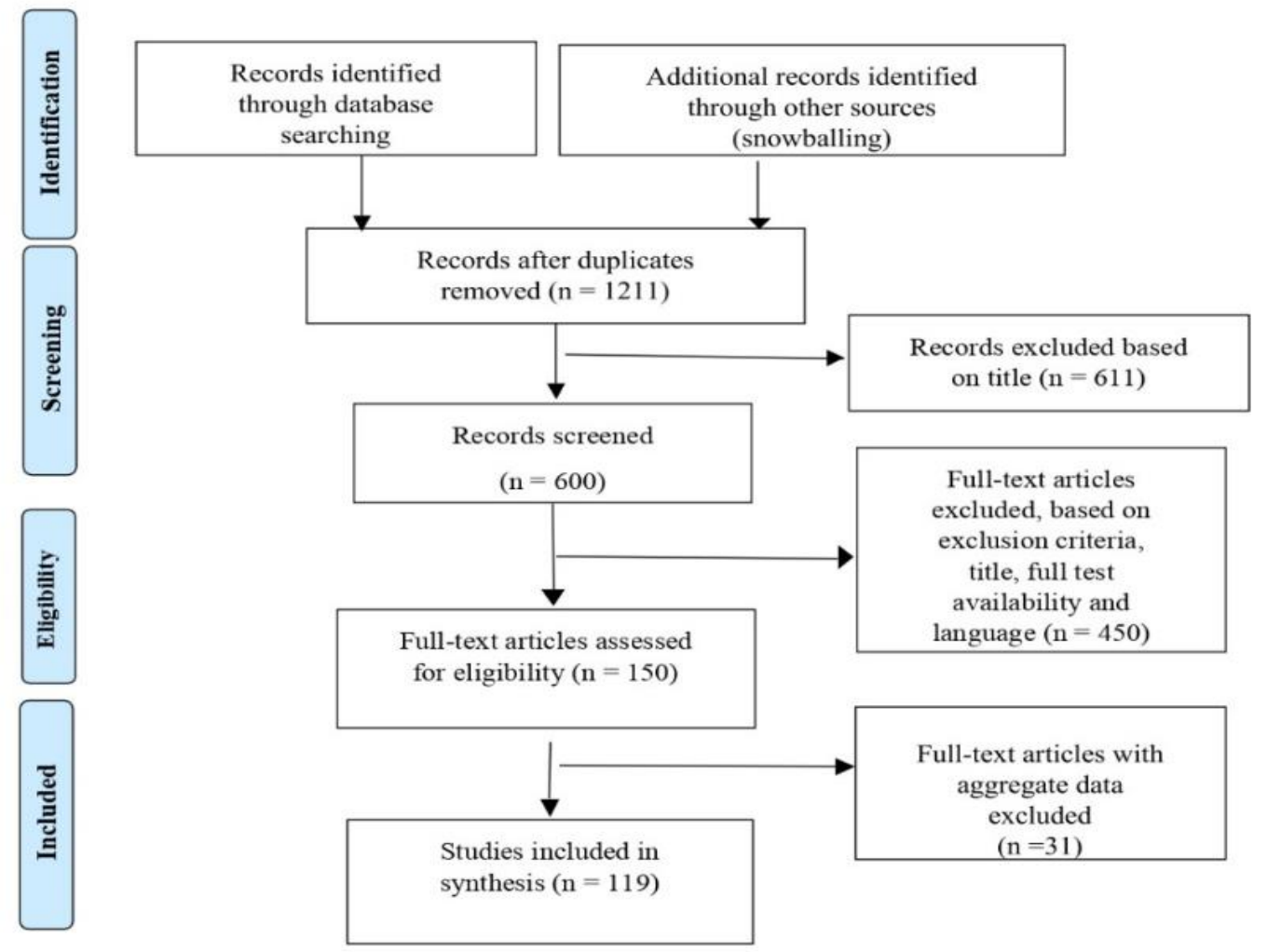

Fig 1: PRISMA (Preferred Reporting Items for Systematic Review and Meta-analysis ) flow chart for study selection

\section{Study Characteristics}

Data of 333 children reported from case series and case reports were compiled. Maximum studies were reported from China $(n=42)$ followed by Italy $(n=14)$, USA $(n=16)$, Spain $(n=6)$, France $(\mathrm{n}=6)$, UK $(\mathrm{n}=6)$ and $\operatorname{Iran}(\mathrm{n}=5)$.

\section{Scoring and classification of MIS-C}

Of the total number of children studied 44/333 (13.3\%) were asymptomatic and 289/333 children (86.7\%) were symptomatic. By applying scoring criteria (Table 1), 52/289 children (17.9\%) could be classified to have MIS-C. All the 52 children were correctly classified as 
medRxiv preprint doi: https://doi.org/10.1101/2021.04.23.21255879; this version posted April 25, 2021. The copyright holder for this preprint (which was not certified by peer review) is the author/funder, who has granted medRxiv a license to display the preprint in perpetuity.

All rights reserved. No reuse allowed without permission.

\section{MIS-C and COVID-19}

MIS-C by two authors blindly thereby validating the robustness of the scoring system. Interestingly, of the selected studies, only $25 / 52$ cases were correctly classified as MIS-C as per WHO Criteria whereas 27 patients were identified as MIS-C as per the scoring system developed herein. Along with fever and raised markers of inflammation (Table 1), most of the children with MIS-C had cardiac involvement (80.8\%), hypotension/shock (75\%), GI manifestations (71.2\%) and coagulopathy (55.8\%) in significant proportion as compared to non MIS-C $(\mathrm{p}=<0.0001)$.

Existing comorbidities were reported in $17.3 \%(\mathrm{n}=9 / 52)$ of children with MIS-C and $13.5 \%$ $(n=32 / 237)$ without MIS-C. This difference was not statistically significant. In the MIS-C group, $63.5 \%$ of children $(n=33 / 52)$ required Intensive Care Unit (ICU) admission while only $15.2 \%(n=36 / 237)$ children in the non-MIS-C group required ICU admission.This difference was statistically significant $<0.0001$.

Table 1: Scoring and proportion of patients with and without various features of Multisystem Inflammatory Syndrome in Children (MIS-C). The p-value (by Chi-square test) compares MIS-C and Non-MIS-C groups.

\begin{tabular}{|c|c|c|c|c|}
\hline Presentation & Score & $\begin{array}{c}\text { MIS-C } \\
n=52(\%)\end{array}$ & $\begin{array}{c}\text { Non-MIS-C } \\
\mathbf{n}=\mathbf{2 3 7}(\%)\end{array}$ & p-value \\
\hline Fever $>3$ days & 3 & $52(100)$ & $153(64.6)$ & - \\
\hline Lab diagnosis of SARS-CoV-2 & 1 & $52(100)$ & $237(100)$ & - \\
\hline $\begin{array}{l}\text { Rash or conjunctivitis or muco- } \\
\text { cutaneous inflammation signs }\end{array}$ & 1 & $18(34.6)$ & $10(4.22)$ & $<0.0001$ \\
\hline Hypotension or shock. & 1 & $39(75)$ & $5(2.11)$ & $<0.0001$ \\
\hline $\begin{array}{l}\text { Diarrhoea, vomiting, or abdominal } \\
\text { pain }\end{array}$ & 1 & $37(71.2)$ & $28(11.9)$ & $<0.0001$ \\
\hline $\begin{array}{l}\text { Features of myocardial dysfunction, } \\
\text { (abnormal eco-cardiography or } \\
\text { elevated Troponin or N-terminal pro } \\
\text { B-type Natriuretic Peptide (NT- } \\
\text { proBNP) }\end{array}$ & 1 & $42(80.8)$ & $3(1.3)$ & $<0.0001$ \\
\hline $\begin{array}{l}\text { Evidence of coagulopathy } \\
\text { (Elevated levels of prothrombin time } \\
\text { PT, partial thromboplastin time PTT } \\
\text { or D-dimer) }\end{array}$ & 1 & $29(55.8)$ & $11(4.7)$ & $<0.0001$ \\
\hline $\begin{array}{l}\text { Evidence of Inflamation } \\
\text { Increased erythrocyte sedimentation } \\
\text { rate (ESR) or C-reactive protein } \\
\text { (CRP) or procalcitonin }\end{array}$ & 1 & $52(100)$ & $70(29.5)$ & $<0.0001$ \\
\hline $\begin{array}{l}\text { Sepsis, } \quad \text { staphylococcal } \\
\text { streptococcal shock syndrome }\end{array}$ & -3 & $0(0)$ & $5(2.11)$ & - \\
\hline
\end{tabular}


medRxiv preprint doi: https://doi.org/10.1101/2021.04.23.21255879; this version posted April 25, 2021. The copyright holder for this preprint (which was not certified by peer review) is the author/funder, who has granted medRxiv a license to display the preprint in perpetuity. All rights reserved. No reuse allowed without permission.

MIS-C and COVID-19

As shown in Table 2, there were no sex biases in MIS-C, non-MIS-C and asymptomatic groups. Maximum numbers of SARS-CoV-2 positive children were reported in the age group of 5-14 years (Table 1) and this age group had a significantly higher proportion of children with MIS-C ( $\mathrm{p}=0.004)$.

Table 2: Age and sex distribution of children with COVID-19 presenting with and without Pediatric Multisystem Inflammatory Syndrome (MIS-C) and asymptomatic presentation. The p-value of each variable (by Chi-square test) comparing MIS-C and Non- MIS-C groups

\begin{tabular}{|l|c|c|c|c|}
\hline & $\begin{array}{c}\text { MIS-C } \\
\mathbf{n = 5 2}(\% \mathbf{\% g e})\end{array}$ & $\begin{array}{c}\text { Non-MIS-C } \\
\mathbf{n = 2 3 7}(\mathbf{\%} \text { age })\end{array}$ & $\begin{array}{c}\text { Asymptomatic } \\
\mathbf{n = 4 4}(\% \text { age })\end{array}$ & p-value \\
\hline Male & $30(58.8)$ & $131(56.2)$ & $29(65.9)$ & 0.486 \\
\hline Female & $21(41.2)$ & $102(43.8)$ & $15(34.1)$ & 0.486 \\
\hline 0-28 days & $2(3.9)$ & $25(10.67)$ & $3(6.8)$ & 0.256 \\
\hline less than 1 year & $5(9.6)$ & $53(22.7)$ & $8(18.2)$ & 0.09 \\
\hline 1-5 years & $9(17.3)$ & $48(20.5)$ & $9(20.5)$ & 0.869 \\
\hline 5-14 years & $34(65.38)$ & $95(40.6)$ & $23(52.3)$ & 0.004 \\
\hline up to 18 years & $2(3.85)$ & $13(5.6)$ & $1(2.3)$ & 0.607 \\
\hline
\end{tabular}

\section{Presenting complaints}

Table 3 compares the clinical presentation in children with and without MIS-C involvement. A significantly higher proportion of children with MIS-C reported fatigue/tiredness and hypotension as compared to children with non-MIS-C. Respiratory symptoms such as breathing difficulty and tachypnoea were significantly more in children with MIS-C. Cough and rhinorrhoea were less common in the MIS-C as compared to the non-MIS-C group.

A significantly greater proportion of children with MIS-C had tachycardia and abnormal ECG on presentation. Vomiting, diarrhea, abdominal pain and dehydration were significantly more common in MIS-C group as compared to non-MIS-C group.

Headache and drowsiness/irritability were more prevalent in children with MIS-C as compared to non-MIS-C group. Convulsions were also reported in a greater proportion in children with MIS-C. Among children with MIS-C, 21\% had conjunctivitis, 32.7\% rash and $13.5 \%$ skin lesions, these were less common in children without MIS-C (3\%, $7 \%$ and 2\% respectively).

Table 3: Comparison of clinical presentation in children with or without Multisystem inflammatory Syndrome (MIS-C). The p-value is comparing MIS-C and Non-MIS-C 
medRxiv preprint doi: https://doi.org/10.1101/2021.04.23.21255879; this version posted April 25, 2021. The copyright holder for this preprint (which was not certified by peer review) is the author/funder, who has granted medRxiv a license to display the preprint in perpetuity.

All rights reserved. No reuse allowed without permission.

MIS-C and COVID-19

\begin{tabular}{|c|c|c|c|}
\hline Presenting Complaints & $\begin{array}{c}\text { MIS-C } \\
\mathrm{n}=52(\%)\end{array}$ & $\begin{array}{c}\text { Non-MIS-C } \\
n=237(\%)\end{array}$ & p-value \\
\hline \multicolumn{4}{|l|}{ General symptoms } \\
\hline Fever & $52(100)$ & $174(73.4)$ & $<0.0001$ \\
\hline Myalgia & $1(1.9)$ & $4(1.7)$ & 0.906 \\
\hline Fatigue & $23(44.2)$ & $20(8.4)$ & $<0.0001$ \\
\hline $\begin{array}{l}\text { Loss of appetite/ reduced oral } \\
\text { intake }\end{array}$ & $7(13.5)$ & $6(2.5)$ & 0.001 \\
\hline Hypotension & $27(51.9)$ & $5(1.7)$ & $<0.0001$ \\
\hline \multicolumn{4}{|l|}{ Respiratory presentation } \\
\hline Cough & $13(25)$ & $119(50.2)$ & 0.001 \\
\hline Breathing difficulty & $24(46.2)$ & $36(15.2)$ & $<0.0001$ \\
\hline Rhinorrhoea & $2(3.8)$ & $54(22.8)$ & 0.002 \\
\hline Sore throat & $7(13.5)$ & $27(11.4)$ & 0.675 \\
\hline Hypoxia & $29(55.8)$ & $56(23.6)$ & 0.029 \\
\hline Apnoea & $1(1.9)$ & $5(2.1)$ & 0.932 \\
\hline Tachypnoea & $25(48.1)$ & $26(10.6)$ & $<0.0001$ \\
\hline Rhonchi/wheeze & $1(1.9)$ & $5(2.1)$ & 0.932 \\
\hline Rales & $5(9.6)$ & $11(4.6)$ & 0.156 \\
\hline \multicolumn{4}{|l|}{ Cardiac presentation } \\
\hline Cyanosis & $1(1.9)$ & $7(2.9)$ & 0.682 \\
\hline Tachycardia & $35(67.3)$ & $24(9.7)$ & $<0.0001$ \\
\hline Chest pain & $1(1.9)$ & $4(1.7)$ & 0.906 \\
\hline Murmur & $1(1.9)$ & $0(0)$ & 0.032 \\
\hline Abnormal ECG & $9(17.3)$ & $0(0)$ & $<0.0001$ \\
\hline \multicolumn{4}{|l|}{ Gastro-intestinal presentation } \\
\hline Nausea/Vomiting & $29(55.8)$ & $19(8.0)$ & $<0.0001$ \\
\hline Diarrhoea & $30(57.7)$ & $22(9.3)$ & $<0.0001$ \\
\hline Dehydration & $24(46.2)$ & $4(1.7)$ & $<0.0001$ \\
\hline Abdominal pain & $20(38.5)$ & $4(1.7)$ & $<0.0001$ \\
\hline Intussusception & $0(0)$ & $1(0.4)$ & 0.639 \\
\hline \multicolumn{4}{|l|}{ Neurological presentation } \\
\hline Headache & $8(15.4)$ & $8(3.38)$ & 0.001 \\
\hline Drowsiness/irritability & $1426.9)$ & $21(8.8)$ & $<0.0001$ \\
\hline Convulsions & $5(9.6)$ & $5(2.1)$ & 0.007 \\
\hline \multicolumn{4}{|l|}{ Others } \\
\hline Conjunctivitis & $11(21.2)$ & $3(1.3)$ & $<0.0001$ \\
\hline Rash & $17(32.7)$ & $7(2.9)$ & $<0.0001$ \\
\hline Skin lesions & $7(13.5)$ & $2(0.8)$ & $<0.0001$ \\
\hline Lymphadenopathy & $3(5.8)$ & $0(0)$ & $<0.0001$ \\
\hline Sepsis & $0(0)$ & $6(2.9)$ & 0.796 \\
\hline Hematuria/Dysuria & $2(3.9)$ & $2(0.8)$ & 0.093 \\
\hline
\end{tabular}


medRxiv preprint doi: https://doi.org/10.1101/2021.04.23.21255879; this version posted April 25, 2021 . The copyright holder for this preprint (which was not certified by peer review) is the author/funder, who has granted medRxiv a license to display the preprint in perpetuity. All rights reserved. No reuse allowed without permission.

\section{MIS-C and COVID-19}

\section{Hematological changes}

As shown in Table 4, a greater proportion of children in the MIS-C group had low hemoglobin as compared to the non-MIS-C group. Leukocytosis, neutrophilia and thrombocytopenia were more common in children with MIS-C as compared to children without MIS-C. However, neutropenia and lymphocytosis were only observed in the nonMIS-C group.

Amongst the inflammatory markers (Table 4), elevated Erythrocyte Sedimentation Rate (ESR), serum C-Reactive Protein (CRP) and Procalcitonin were found in significantly higher proportion of children with MIS-C as compared to non-MIS-C. Similarly, a significantly greater proportion of children with MIS-C had elevated serum Ferritin, Lactate Dehydrogenase (LDH), Fibrinogen and IL-6 as compared to their non-MIS-C counterparts.

Elevated levels of coagulation markers like prothrombin time (PT), partial thromboplastin time PTT) and D-dimer were found in significantly greater proportion of children with MIS$\mathrm{C}$ as compared to non-MIS-C group (Table 4). A significantly greater proportion of children in the MIS-C group had raised levels of liver function markers compared to the non-MIS-C group. Elevated levels of renal function markers were observed in a significantly higher proportion of children with MIS-C as compared to non-MIS-C groups.

\section{Cardiac dysfunction}

Amongst cardiac enzymes, creatinine kinase-MB (CK-MB), Troponin and N-terminal proBrain Natriuretic Peptide were elevated in a significantly higher proportion of children with MIS-C. Echocardiography was abnormal in 26 children with MIS-C and 4 children without MIS-C.

\section{Radiographic changes}

Chest X-ray abnormalities were reported in $42.3 \%$ of children with MIS-C and $24 \%$ of children without MIS-C ( $\mathrm{p}=0.007)$. As compared to MIS-C group, a significantly greater proportion of children without MIS-C had abnormal HRCT (High-Resolution Computer Tomography) and this difference was statistically significant ( $\mathrm{p}=0.0001)$. 
medRxiv preprint doi: https://doi.org/10.1101/2021.04.23.21255879; this version posted April 25, 2021 . The copyright holder for this preprint (which was not certified by peer review) is the author/funder, who has granted medRxiv a license to display the preprint in perpetuity.

All rights reserved. No reuse allowed without permission.

MIS-C and COVID-19

Table 4: Comparision of Hematological investigations and Cardiac dysfunction in children with and without Pediatric Multisystem inflammatory Syndrome (MIS-C)

\begin{tabular}{|c|c|c|c|c|c|}
\hline & \multicolumn{2}{|c|}{ MIS-C $(n=52)$} & \multicolumn{2}{|c|}{ Non-MIS-C $(n=237)$} & \multirow[b]{2}{*}{ p-value } \\
\hline $\begin{array}{l}\text { Laboratory } \\
\text { investigations }\end{array}$ & $\begin{array}{c}\text { Tests results } \\
\text { available }\end{array}$ & n (\%) & $\begin{array}{c}\text { Tests results } \\
\text { available }\end{array}$ & n (\%age) & \\
\hline \multicolumn{6}{|c|}{ Complete blood counts } \\
\hline$\downarrow \mathbf{H b}$ & 48 & $10(20.8)$ & 195 & $11(5.6)$ & 0.01 \\
\hline$\uparrow \mathbf{W B C}$ & 48 & $13(27.1)$ & 194 & $21(10.8)$ & 0.004 \\
\hline$\downarrow \mathbf{W B C}$ & 48 & $13(27.1)$ & 194 & $38(19.6)$ & 0.460 \\
\hline$\uparrow \mathbf{A N C}$ & 48 & $20(41.7)$ & 192 & $11(5.7)$ & $<0.0001$ \\
\hline$\downarrow$ ANC & 48 & $0(0.0)$ & 192 & $43(22.4)$ & $<0.0001$ \\
\hline$\uparrow \mathbf{A L C}$ & 48 & $0(0.0)$ & 192 & $3(18.8)$ & 0.001 \\
\hline$\downarrow \mathbf{A L C}$ & 48 & $26(54.2)$ & 192 & $57(29.7)$ & 0.001 \\
\hline$\downarrow$ Platelets & 48 & $16(33.3)$ & 195 & $11(5.6)$ & $<0.0001$ \\
\hline \multicolumn{6}{|c|}{ Inflammatory Markers } \\
\hline$\uparrow \mathbf{E S R}$ & 30 & $15(46.9)$ & 127 & $11(8.7)$ & $<0.0001$ \\
\hline$\uparrow \mathbf{C R P}$ & 52 & $49(96.1)$ & 152 & $44(29.0)$ & $<0.0001$ \\
\hline$\uparrow$ Procalcitonin & 29 & $25(86.2)$ & 78 & $39(50.0)$ & 0.001 \\
\hline$\uparrow$ Ferritin & 31 & $24(77.4)$ & 13 & $4(30.8)$ & 0.003 \\
\hline$\uparrow \mathbf{L D H}$ & 12 & $8(66.7)$ & 74 & $27(36.5)$ & 0.048 \\
\hline$\uparrow$ Fibrinogen & 13 & $10(77.0)$ & 18 & $1(5.6)$ & $<0.0001$ \\
\hline$\uparrow$ IL-6 & 17 & $14(82.4)$ & 23 & $12(52.2)$ & 0.048 \\
\hline \multicolumn{6}{|c|}{ Coagulation markers } \\
\hline$\uparrow$ APTT & 5 & $3(60)$ & 31 & $1(3.2)$ & $<0.0001$ \\
\hline$\uparrow \mathbf{P T}$ & 6 & $4(66)$ & 33 & $0(0.0)$ & $<0.0001$ \\
\hline$\uparrow$ D-Dimer & 23 & $22(95.6)$ & 39 & $10(34.5)$ & $<0.0001$ \\
\hline \multicolumn{6}{|c|}{ Other investigations } \\
\hline$\uparrow$ AST/SGOT & 32 & $14(43.8)$ & 75 & $13(17.3)$ & 0.004 \\
\hline$\uparrow$ ALT/SGPT & 32 & $14(43.8)$ & 81 & $15(18.5)$ & 0.006 \\
\hline$\uparrow$ Urea & 26 & $7(27.0)$ & 63 & $0(0.0)$ & $<0.0001$ \\
\hline$\uparrow$ Creatinine & 26 & $10(38.5)$ & 64 & $5(4.7)$ & $<0.0001$ \\
\hline$\uparrow \mathbf{C K}$ & 35 & $5(29.4)$ & 179 & $10(17.2)$ & 0.270 \\
\hline$\uparrow \mathbf{C K}-\mathrm{MB}$ & 49 & $1(33.3)$ & 211 & $1(3.9)$ & 0.056 \\
\hline$\uparrow$ Troponin & 14 & $31(81.6)$ & 223 & $1(7.1)$ & $<0.0001$ \\
\hline$\uparrow$ Myoglobin & 50 & $0(0.0)$ & 234 & $1(33.3)$ & 0.361 \\
\hline$\uparrow$ Pro-BNP & 28 & $24(100)$ & 234 & $0(0.0)$ & $<0.0001$ \\
\hline $\begin{array}{l}\text { Abnormal } \\
\text { echocardiogram }\end{array}$ & 10 & $26(70.0)$ & 229 & $4(66.7)$ & 0.858 \\
\hline
\end{tabular}

Abbreviations: Hb: Hemoglobin WBC: Whole blood counts ANC: Absolute Neutrophils count ALC: Absolute Lymphocyte Count CRP: C Reactive Protein LDH: Lactic acid Dehydrogenase IL-6: Interleukin 6. APTT: Activated Partial Thromboplastin time PTT: Partial Thromboplastin Time AST/SGOT: Aspartate aminotransferase/serum glutamic oxaloacetic transaminase ALT/SGPT: alanine aminotransferase/ serum glutamic-pyruvic transaminase CK-Creatinine Kinase CK-MB: Creatine kinase myocardial band Pro-BNP: N-terminal pro-Brain Natriuretic Peptide ABN ECHO: Abnormal Echocardiography 
medRxiv preprint doi: https://doi.org/10.1101/2021.04.23.21255879; this version posted April 25, 2021. The copyright holder for this preprint (which was not certified by peer review) is the author/funder, who has granted medRxiv a license to display the preprint in perpetuity.

All rights reserved. No reuse allowed without permission.

MIS-C and COVID-19

\section{Clinical Management}

Antiviral medications such as Oseltamivir, Lopinavir/Ritonavir, and Ribavirin were used in a higher proportion in the non-MIS-C group as compared to the MIS-C group. Methylprednisolone was more commonly used in children with MIS-C as compared to those without MIS-C. Immunoglobulins were used in $63.5 \%$ of children with MIS-C and $3.4 \%$ in children without MIS-C. Tocilizumab was used in 4 children with MIS-C and 2 children without MIS-C. Use of Infliximab was reported in 2 children with MIS-C (Table 5).

The use of intensive modalities was significantly higher in children with MIS-C. Oxygen supplementation, non-invasive ventilation, mechanical ventilation and inotropes were commonly used in children with MIS-C.

Aspirin and intravenous anticoagulation usage were reportedly used in children with MIS-C; Hydroxychloroquine was used in $21.2 \%$ of children with MIS-C and $7.2 \%$ of children without MIS-C. Antibiotic use was reported in $77 \%$ of children with MIS-C and $67 \%$ of children without MIS-C (Table 5). Mortality rates were significantly higher in children with MIS-C (Table 5).

Table 5: Comparison of management strategies in children with COVID-19 with or without Multisystem inflammatory Syndrome in Children (MIS-C).

\begin{tabular}{|l|c|c|c|}
\hline & MIS-C n=52 (\%) & Non-MIS-C n=237 (\%) & P-value \\
\hline Antiviral Medications & $9(17.3)$ & $68(28.7)$ & 0.093 \\
\hline Steroids & $27(52.0)$ & $11(4.7)$ & $<0.00001$ \\
\hline IV Immune globulin & $33(63.5)$ & $8(3.4)$ & $<0.00001$ \\
\hline Interferon -1B Inhalation & $3(5.8)$ & $37(15.6)$ & 0.061 \\
\hline Tocilizumab and Infliximab & $5(9.7)$ & $2(0.9)$ & 0.003 \\
\hline Anticoagulation & $0(0.0)$ & $<0.00001$ \\
\hline Aspirin & $14(26.9)$ & $1(0.4)$ & $<0.00001$ \\
\hline IV anticoagulation & $11(21.1)$ & $49(20.7)$ & $<0.00001$ \\
\hline Respiratory support & $39(75)$ & $9(3.8)$ & $<0.00001$ \\
\hline Oxygen & $11(21.2)$ & $6(2.5)$ & $<0.00001$ \\
\hline Non invasive ventilation & $17(32.7)$ & $1(0.4)$ & 1.000 \\
\hline Mechanical Ventilation & $0(0)$ & $2(0.8)$ & $<0.00001$ \\
\hline High flow ventilation & $28(53.8)$ & $17(7.2)$ & 0.002 \\
\hline Inotropes & $11(21.2)$ & $67(28.9)$ & $<0.00001$ \\
\hline Hydroxychloroquine & $40(76.9)$ & $0(0.0)$ & 0.0056. \\
\hline Antibiotic & $3(5.8)$ & $219(92.4)$ & $<0.00001$ \\
\hline Miscellaneous & $32(61.0)$ & $1(0.4)$ & 0.001 \\
\hline ECMO, Plasmapheresis & $5(9.6)$ & & \\
\hline Discharged &
\end{tabular}

ECMO- Extra corporeal membrane oxygenation 
medRxiv preprint doi: https://doi.org/10.1101/2021.04.23.21255879; this version posted April 25, 2021. The copyright holder for this preprint (which was not certified by peer review) is the author/funder, who has granted medRxiv a license to display the preprint in perpetuity.

All rights reserved. No reuse allowed without permission.

MIS-C and COVID-19

\section{Discussion}

The present systematic review compared the clinical presentation, laboratory parameters and management strategies used in symptomatic SARS-CoV-2 positive children with and without MIS-C. The results reveal that the COVID-19 children with MIS-C have a more severe presentation, higher adverse outcomes and required aggressive management modalities as compared to their non-MIS-C counterparts.

Several studies and systematic reviews have been published describing the clinical presentations and outcomes of children with COVID-19 presenting with MIS-C ${ }^{18 i ̈ 21}$. However, a major limitation of the systematic reviews is that the clinical case definition of MIS-C was as per the author criteria which vary significantly between different studies. Further, as definition of MIS-C is an evolving concept, many studies have misclassified the cases in absence of an objective criteria. To attain objectivity and uniformity across studies we first evolved a scoring system for the clinical signs of MIS-C as per WHO criteria. We gave the highest weightage to fever as it is a mandatory requirement to classify MIS-C as per WHO criteria. As not all children will present with all the symptoms, a score of 1 was given for other parameters. As septicemia can also present like MIS-C ${ }^{22}$, it is necessary to rule out sepsis in the children. A high negative score for sepsis was thus included to provide an accurate differential diagnosis of COVID-19 associated MIS-C. This scoring system was implemented on the primary data collected for 333 children and two authors accurately classified 52 children having MIS-C. Although this scoring needs to be clinically validated in a hospital setup, we believe that our scoring system is robust and can be utilized by clinicians to classify MIS-C.

Overall our study estimated the prevalence of MIS-C in $21 \%$ of children with symptomatic COVID-19. We next used our scoring system to compare the presentation of 52 children with MIS-C vs 237 non-MIS-C cases. We noted that the risk of MIS-C is low ( 10\%) in children with COVID-19 below one year of age which increased to almost $17 \%$ in the age group of 15 years. However, a large number of children (65\%) with COVID-19 in the age group of 5-14 years developed MIS-C. Similar to observational studies ${ }^{12,23}$, our systematic review shows that the disease is of higher preponderance in the age group of 5-14 years. This age distribution is different from that of classical Kawasaki disease which is common in children of younger age $\mathrm{a}^{24}$. Thus, children in the age group of 5-14 years developing symptomatic COVID-19 disease must be closely monitored for progression towards MIS-C. 
medRxiv preprint doi: https://doi.org/10.1101/2021.04.23.21255879; this version posted April 25, 2021. The copyright holder for this preprint (which was not certified by peer review) is the author/funder, who has granted medRxiv a license to display the preprint in perpetuity.

All rights reserved. No reuse allowed without permission.

MIS-C and COVID-19

It was observed that beyond inflammation and fever, the children with MIS-C had more severity at presentation. Almost $75-80 \%$ of the children with MIS-C and COVID-19 had gastrointestinal involvements which were rarely seen in COVID-19 children without MIS-C involvement. Clinicians should be alert to notice signs and symptoms such as nausea/vomiting, abdominal pain and diarrhea for an impending MIS-C.

We observed that cardiac dysfunctions are very common in the MIS-C group as compared to non-MIS-C group. Cardiac dysfunctions in the form of tall and wide P waves, ST-segment abnormalities, T negative waves are reported in a proportion of children with COVID-19 $14,24 i$ 26. However, coronary artery involvement in form of diffuse ectasia and dilatation was reported in relatively fewer cases of children with COVID-19 ${ }^{11,28 i 30}$. It is known that cardiac enzymes such as CK, CK-MB, Troponin and N-terminal pro-Brain Natriuretic Peptide are elevated in a proportion of children with COVID-19 $11,12,26,30,31$. We observed that these markers were mostly elevated in children with MIS-C and not so in the non-MIS-C group. Neurological defects are reported in some cases of children with COVID-19 $26,32 i$ ï . Herein we observed a reasonable preponderance of neurological involvement such as headache, convulsions encephalitis and meningoencephalitis in the MIS-C group implying the need for follow-up for long-term neurological deficits in children with COVID-19. Thus, while managing pediatric cases of COVID-19, clinicians must pay attention to symptoms such as encephalitis, headache or convulsions for possible development of MIS-C.

Serum biochemistry is indispensable in the differential diagnosis of many conditions in children. Many biochemical parameters such as inflammatory markers, cardiac and liver enzymes are reportedly altered in children with MIS-C. More than $80 \%$ of children with MIS-C had raised IL-6 which is an important marker for cytokine storm ${ }^{14,25,29,33,38 і ̈ 40}$. Our study revealed that the traditional inflammatory markers such as raised ESR, CRP, IL-6 and Procalcitonin are observed in children with MIS-C. However, for these markers to be diagnostic of MIS-C, septicemia should be ruled out which often is time-consuming and reports may not be readily available. Based on our study we propose that elevated coagulation markers (PTT, PT, and D-Dimers) along with elevated cardiac markers such as Troponin and pro-BNP could be useful surrogates to identify MIS-C in COVID-19 children with MIS-C. Larger clinical studies will be required to determine the sensitivity and specificity of these markers for their diagnostic use in COVID-19 related MIS-C.

Children with COVID-19 and MIS-C required aggressive management strategies. Intensive care admissions were significantly more common in MIS-C group as compared with children without MIS-C presentation. Based on the presenting phenotypes, authors reported the use of 
medRxiv preprint doi: https://doi.org/10.1101/2021.04.23.21255879; this version posted April 25, 2021. The copyright holder for this preprint (which was not certified by peer review) is the author/funder, who has granted medRxiv a license to display the preprint in perpetuity.

All rights reserved. No reuse allowed without permission.

MIS-C and COVID-19

antibiotics, steroids, immunoglobulins and inotropes in children with MIS-C. Even though septicemia is an exclusion criterion for MIS-C, antibiotics use was reported in $77 \%$ of cases with COVID-19 related MIS-C. Clinicians must be aware of the fact that bacterial septicemia is rare in children with COVID-19 and MIS-C and hence antibiotics will be ineffective and should be avoided. Use of Tocilizumab and Infliximab was reported in children with MIS-C with elevated IL-6 levels ${ }^{14,38,40}$. Use of recombinant IL-1 receptor antagonist (Anakinra) was reported in a study from UK with high IL-1 values ${ }^{29}$. Anticoagulation therapy such as prophylactic low molecular weight Heparin and Enoxaparin was mainly reported in case of severe cardiac involvement ${ }^{14,25,41}$. Aspirin use was mainly reported in children with Kawasaki like presentation ${ }^{12,42 i ̈ 4}$. These observations point towards evolving need for prophylactic anticoagulation in the treatment of MIS-C. Unfortunately, in absence of the data on the effectiveness of these therapies, it is difficult to comment which of these could be beneficial. The recovery rate was higher in the non-MIS-C group and overall mortality was only $1.8 \%$, while the mortality was almost $10 \%$ in children with MIS-C. Although the numbers of children are fewer, this preliminary analysis suggests that MIS-C is associated with high morbidity and mortality

Although, the presentations of MIS-C in children with COVID-19 strongly overlap with that of Kawasaki disease, clinically MIS-C seems to significantly differ from classical KD. MIS$\mathrm{C}$ commonly affects older children and adolescents, whereas classic KD typically affects infants and young children. The diagnosis of $\mathrm{KD}$ requires the presence of fever lasting at least 5 days with at least 4 of the 5 signs of mucocutaneous inflammation. Amongst these, oral mucous membrane involvement, polymorphous rash, extremity changes, ocular changes, and cervical lymphadenopathy are common in $\mathrm{KD}^{45 i ̈ 48}$. Other findings such as gastrointestinal symptoms are common in MIS-C compared to classic $\mathrm{KD}^{24,49}$. Additionally, approximately $30 \%$ of patients with $\mathrm{KD}$ have dilatation of coronary arteries ${ }^{50,51}$. Amongst the hematological parameters, decreased hemoglobin, lymphopenia thrombocytopenia along with elevated inflammatory markers were characteristically reported in MIS-C contrary to thrombocytosis with lymphocytosis which is more evident in typical $\mathrm{KD}^{12,14,43,44,52 i ̈ 54,26,28 i}$ $31,39,40,42$

Similarly, differentiating MIS-C and acute COVID-19 is also crucial. The patterns of clinical presentation and organ system involvement differentiate MIS-C from severe acute COVID$19^{55,56,57}$. Severe pulmonary involvement (pneumonia and acute respiratory distress syndrome) is characteristic of severe acute COVID-19 as it is more common in cases without MIS-C. In cases with MIS-C, it is often secondary to cardiac dysfunction. Further, 
medRxiv preprint doi: https://doi.org/10.1101/2021.04.23.21255879; this version posted April 25, 2021. The copyright holder for this preprint (which was not certified by peer review) is the author/funder, who has granted medRxiv a license to display the preprint in perpetuity. All rights reserved. No reuse allowed without permission.

\section{MIS-C and COVID-19}

myocardial dysfunction, muco-cutaneous and gastrointestinal involvement are more common in MIS-C than in severe acute COVID-19. Elevated inflammatory markers, lymphopenia and thrombocytopenia tend to be more common in MIS-C. SARS-CoV-2 antibody titres may also be higher in patients with MIS-C compared with acute COVID-19 ${ }^{58}$. Although all these need to be systematically investigated to determine the accurate clinical and laboratory markers for a differential diagnosis of MIS-C and acute COVID-19 in children.

\section{Conclusion}

Multisystem inflammatory involvement in pediatric COVID-19 is a distinct entity and is not rare as previously thought. The clinical spectrum of MIS-C appears to differ from typical Kawasaki presentation reiterating that MIS-C could be a peculiar phenomenon of COVID-19. In the background of increasing diversity of COVID-19 presentation in pediatric age group and in the wake of second wave of COVID-19, timely diagnosis and management of MIS-C is utmost importance. The scoring proposed in this review may be adapted for meticulous identification of children with MIS-C in SARS-CoV-2 infection. The information generated in this review should act as a primer to consider MIS-C as a distinct presentation of COVID19 in pediatric age groups. The results will aid in decision-making for devising diagnostics and treatment modalities for MIS-C and Covid-19.

Ethical Approval: The present systematic review is under exempt category as per Institutional Ethics Committee (ID-ICEC/Sci-50/53/2020).

Acknowledgments: The study is supported by grants from the Indian Council of Medical Research (ICMR) intramural funding to NIRRH. The manuscript bears ICMR-NIRRH ID RA/948/07-2020.

Author contribution: SS, SM, and DM conceived the study. SS and SJ collected and analyzed the literature and shortlisted the studies. SS extracted the data and RG verified it. SM coordinated the study. 
medRxiv preprint doi: https://doi.org/10.1101/2021.04.23.21255879; this version posted April 25, 2021. The copyright holder for this preprint (which was not certified by peer review) is the author/funder, who has granted medRxiv a license to display the preprint in perpetuity. All rights reserved. No reuse allowed without permission.

\section{MIS-C and COVID-19}

\section{References}

1 Ludvigsson JF. Systematic review of COVID-19 in children shows milder cases and a better prognosis than adults. Acta Paediatr 2020; 109: 1088ї 1095. doi: 10.1111/apa.15270.

2 Jordan RE, Adab P, Cheng KK. Covid-19: Risk factors for severe disease and death. BMJ 2020; 368: m1198. doi:10.1136/bmj.m1198.

3 Qiu H, Wu J, Hong L, Luo Y, Song Q, Chen D. Clinical and epidemiological features of 36 children with coronavirus disease 2019 (COVID-19) in Zhejiang, China: an observational cohort study. Lancet Infect Dis 2020; 20: 689ї 696. doi: 10.1016/S14733099(20)30198-5.

4 Castagnoli R, Votto M, Licari A, Brambilla I, Bruno R, Perlini S et al. Severe Acute Respiratory Syndrome Coronavirus 2 (SARS-CoV-2) Infection in Children and Adolescents: A Systematic Review. JAMA Pediatr 2020; 174: 882-889 doi:10.1001/jamapediatrics.2020.1467.

5 Parri N, Lenge M, Buonsenso D. Children with Covid-19 in Pediatric Emergency Departments in Italy. N Engl J Med 2020; 383: 187-190. doi:10.1056/nejmc2007617.

6 Jordan-Villegas A, Chang ML, Ramilo O, Mejías A. Concomitant respiratory viral infections in children with kawasaki disease. Pediatr Infect Dis J 2010; 29: 770 ï 772. doi: 10.1097/INF.0b013e3181dba70b.

7 Chang LY, Lu CY, Shao PL, Lee PI, Lin MT, Fan TY et al. Viral infections associated with Kawasaki disease. J Formos Med Assoc 2014; 113: 148ї 154. doi:

10.1016/j.jfma.2013.12.008

8 Shike H, Shimizu C, Kanegaye JT, Foley JL, Schnurr DP, Wold LJ et al. Adenovirus, adeno-associated virus and Kawasaki disease. Pediatr Infect Dis J 2005; 24: 1011 1014. doi: 10.1097/01.inf.0000183769.31951.1e.

9 Wang J, Sun F, Deng HL, Liu RQ. Influenza A (H1N1) pdm09 virus infection in a patient with incomplete Kawasaki disease: A case report. Medicine (Baltimore) 2019; 98: e15009. doi: 10.1097/MD.0000000000015009

10 Weng KP, Cheng-Chung Wei J, Hung YM, Huang SH, Chien KJ, Lin CC et al. Enterovirus Infection and Subsequent Risk of Kawasaki Disease: A Population-based Cohort Study. Pediatr Infect Dis J 2018; 37: 310ї 315. doi:

10.1097/MD.0000000000015009. 
medRxiv preprint doi: https://doi.org/10.1101/2021.04.23.21255879; this version posted April 25, 2021. The copyright holder for this preprint (which was not certified by peer review) is the author/funder, who has granted medRxiv a license to display the preprint in perpetuity. All rights reserved. No reuse allowed without permission.

\section{MIS-C and COVID-19}

11 Riphagen S, Gomez X, Gonzalez-Martinez C, Wilkinson N, Theocharis P. Hyperinflammatory shock in children during COVID-19 pandemic. Lancet. 2020; 395: 1607ï 1608. doi: 10.1016/S0140-6736(20)31094-1.

12 Verdoni L, Mazza A, Gervasoni A, Martelli L, Ruggeri M, Ciuffreda M et al. An outbreak of severe Kawasaki-like disease at the Italian epicentre of the SARS-CoV-2 epidemic: an observational cohort study. Lancet 2020; 395: 1771ї 1778. doi: 10.1016/S0140-6736(20)31103-X.

13 Belhadjer Z, Méot M, Bajolle F, Khraiche D, Legendre A, Abakka S et al. Acute heart failure in multisystem inflammatory syndrome in children (MIS-C) in the context of global SARS-CoV-2 pandemic. Circulation 2020; 142: 429ї 436. doi: 10.1161/CIRCULATIONAHA.120.048360.

14 Wolfler A, Mannarino S, Giacomet V, Camporesi A, Zuccotti G. Acute myocardial injury: a novel clinical pattern in children with COVID-19. Lancet Child Adolesc Heal 2020; 4: e26-e27. doi:10.1016/s2352-4642(20)30168-1.

15 Xu S, Chen M, Weng J. COVID-19 and Kawasaki disease in children. Pharmacol. Res. 2020; 159: 104951. doi: 10.1016/j.phrs.2020.104951.

16 World Health Organization. Multisystem inflammatory syndrome in children and adolescents temporally related to COVID-19: Scientific Brief.

2020.https://www.who.int/news-room/commentaries/detail/multisystem-inflammatorysyndrome-in-children-and-adolescents-with-covid-19 (accessed 12 Ju12020).

17 Centers for Disease Control and Prevention Health Alert Network (HAN). Multisystem Inflammatory Syndrome in Children (MIS-C) Associated with Coronavirus Disease 2019 (COVID-19).

https://emergency.cdc.gov/han/2020/han00432.asp (accessed 19 Apr2021).

18 Sood M, Sharma S, Sood I, Sharma K, Kaushik A. Emerging Evidence on Multisystem Inflammatory Syndrome in Children Associated with SARS-CoV-2 Infection: a Systematic Review with Meta-analysis. SN Compr Clin Med 2021;1ї 10. doi: 10.1007/s42399-020-00690-6.

19 Ahmed M, Advani S, Moreira A, Zoretic S, Martinez J, Chorath K et al. Multisystem inflammatory syndrome in children: A systematic review. EClinicalMedicine 2020; 26: 100527. doi:10.1016/j.eclinm.2020.100527.

20 Radia T, Williams N, Agrawal P, Harman K, Weale J, Cook J et al. Multi-system inflammatory syndrome in children \& adolescents (MIS-C): A systematic review of clinical features and presentation. Paediatr Respir Rev 2020. S1526-0542(20)30117-2. 
medRxiv preprint doi: https://doi.org/10.1101/2021.04.23.21255879; this version posted April 25, 2021. The copyright holder for this preprint (which was not certified by peer review) is the author/funder, who has granted medRxiv a license to display the preprint in perpetuity. All rights reserved. No reuse allowed without permission.

\section{MIS-C and COVID-19}

doi:10.1016/j.prrv.2020.08.001.

21 Abrams JY, Godfred-Cato SE, Oster ME, Chow EJ, Koumans EH, Bryant B et al. Multisystem Inflammatory Syndrome in Children Associated with Severe Acute Respiratory Syndrome Coronavirus 2: A Systematic Review. J Pediatr 2020; 226: $45-$ 54. doi: 10.1016/j.jpeds.2020.08.003.

22 Cook J, Harman K, Zoica B, Verma A, Dôsilva P, Gupta A. Horizontal transmission of severe acute respiratory syndrome coronavirus 2 to a premature infant: multiple organ injury and association with markers of inflammation. Lancet Child Adolesc Heal 2020; 4: 548-551. doi: 10.1016/S2352-4642(20)30166-8.

23 Toubiana J, Poirault C, Corsia A, Bajolle F, Fourgeaud J, Angoulvant F et al. Kawasaki-like multisystem inflammatory syndrome in children during the covid-19 pandemic in Paris, France: prospective observational study. BMJ 2020; 369: m2094. doi: 10.1136/bmj.m2094.

24 McCrindle BW, Rowley AH, Newburger JW, Burns JC, Bolger AF, Gewitz M et al. Diagnosis, treatment, and long-term management of Kawasaki disease: A scientific statement for health professionals from the American Heart Association. Circulation 2017; 135: e927ї e999. doi: 10.1161/CIR.0000000000000484.

25 Oberweis ML, Codreanu A, Boehm W, Olivier D, Pierron C, Tsobo C et al. Pediatric Life-Threatening Coronavirus Disease 2019 With Myocarditis. Pediatr Infect Dis $J$ 2020; 39: e147ï e149. doi: 10.1097/INF.0000000000002744.

26 Latimer G, Corriveau C, DeBiasi RL, Jantausch B, Delaney M, Jacquot C et al. Cardiac dysfunction and thrombocytopenia-associated multiple organ failure inflammation phenotype in a severe paediatric case of COVID-19. Lancet Child Adolesc Heal 2020; 4: 552-554. doi: 10.1016/S2352-4642(20)30163-2.

27 Yildirim, A.I., Karaagac A. Clinical Case Letter COVID-19 in a Young Girl with Restrictive Cardiomyopathy and Chronic Lung Disease. Indian Pediatr 2020; 57: 577 ï 578. doi: 10.1007/s13312-020-1863-1.

28 Acharyya, B. C., Acharyya, S., \& Das, D. Novel Coronavirus Mimicking Kawasaki Disease in an Infant - PubMed. Indian Pediatr 2020; 57: 753 ï 754. doi.org/10.1007/s13312-020-1924-5.

29 Pain CE, Felsenstein S, Cleary G, Mayell S, Conrad K, Harave S et al. Novel paediatric presentation of COVID-19 with ARDS and cytokine storm syndrome without respiratory symptoms. Lancet Rheumatol 2020; 2: e376-e379. doi: 10.1016/S2665-9913(20)30137-5. 
medRxiv preprint doi: https://doi.org/10.1101/2021.04.23.21255879; this version posted April 25, 2021. The copyright holder for this preprint (which was not certified by peer review) is the author/funder, who has granted medRxiv a license to display the preprint in perpetuity. All rights reserved. No reuse allowed without permission.

\section{MIS-C and COVID-19}

30 Kathleen Chiotos, Hamid Bassiri, Edward M Behrens, Allison M Blatz, Joyce Chang, Caroline Diorio, Julie C Fitzgerald, Alexis Topjian AROJ. Multisystem Inflammatory Syndrome in Children During the Coronavirus 2019 Pandemic: A Case Series. $J$ Pediatric Infect Dis Soc 2020; 9: 393ї 398. doi: 10.1093/jpids/piaa069.

31 Giacomet V, Manfredini VA, Meraviglia G, Peri CF, Sala A, Longoni E et al. Acute Inflammation and Elevated Cardiac Markers in a Two-Month-Old Infant with Severe Acute Respiratory Syndrome Coronavirus 2 Infection Presenting with Cardiac Symptoms. Pediatr Infect Dis J 2020; 39: e149ï e151. doi: 10.1097/INF.0000000000002750.

32 McAbee GN, Brosgol Y, Pavlakis S, Agha R, Gaffoor M. Encephalitis Associated with COVID-19 Infection in an 11 Year-Old Child. Pediatr Neurol 2020; 109: 94. doi: 10.1016/j.pediatrneurol.2020.04.013.

33 Klocperk A, Parackova Z, Dissou J, Malcova H, Pavlicek P, Vymazal T et al. Systemic inflammatory response and fast recovery in a pediatric patient with COVID19. Front Immunol 2020; 11: 1665. doi: 10.3389/fimmu.2020.01665.

34 Lorenz, Norbert MD; Treptow, Anna MD; Schmidt, Stefan MD; Hofmann, René MD; Raumer-Engler, Mandy MD; Heubner, Georg MD; Gröber KM. Neonatal Early-Onset Infection With SARS-CoV-2 in a Newborn Presenting With Encephalitic Symptoms. Pediatr Infect Dis J 2020; 39: e212. doi: 10.1097/INF.0000000000002735.

35 Sun D, Li H, Lu XX, Xiao H, Ren J, Zhang FR et al. Clinical features of severe pediatric patients with coronavirus disease 2019 in Wuhan: a single centerô observational study. World J Pediatr 2020; 16: 251-259. doi:10.1007/s12519-02000354-4.

36 Chacón-Aguilar R, Osorio-Cámara JM, Sanjurjo-Jimenez I, González-González C, López-Carnero J, Pérez-Moneo B. COVID-19: Fever syndrome and neurological symptoms in a neonate. An Pediatría (English Ed) 2020; 92: 373-374. doi: 10.1016/j.anpede.2020.04.001.

37 Dugue R, Cay-Martínez KC, Thakur KT, Garcia JA, Chauhan L V., Williams SH et al. Neurologic manifestations in an infant with COVID-19. Neurology 2020; 94: 11001102. doi: 10.1212/WNL.0000000000009653.

38 Dolinger MT, Person H, Smith R, Jarchin L, Pittman N, Dubinsky MC et al. Pediatric Crohnôs disease and multisystem inflammatory syndrome in children (MIS-C) and COVID-19 treated with infliximab. J Pediatr Gastroenterol Nutr 2020; 71: 153-155. doi:10.1097/MPG.0000000000002809. 
medRxiv preprint doi: https://doi.org/10.1101/2021.04.23.21255879; this version posted April 25, 2021. The copyright holder for this preprint (which was not certified by peer review) is the author/funder, who has granted medRxiv a license to display the preprint in perpetuity. All rights reserved. No reuse allowed without permission.

\section{MIS-C and COVID-19}

39 Feng C, Zhisheng L, Furong Z, Ruihua X, Yang C, Xingfeng C et al. First case of severe childhood novel coronavirus pneumonia in China. Zhonghua Er Ke Za Zhi 2020; 58: $179 і ̈$ 182. doi: 10.3760/cma.j.issn.0578-1310.2020.03.003.

Cabrero-Hernández M, García-Salido A, Leoz-Gordillo I, Alonso-Cadenas JA, GochiValdovinos A, González Brabin A, et al. Severe SARS-CoV-2 Infection in Children With Suspected Acute Abdomen: A Case Series From a Tertiary Hospital in Spain. Pediatr Infect Dis J 2020; 39: e195-e198. doi:10.1097/INF.0000000000002777.

41 Odièvre MH, de Marcellus C, Ducou Le Pointe H, Allali S, Romain AS, Youn J et al. Dramatic improvement after Tocilizumab of a severe COVID-19 in a child with sickle cell disease and acute chest syndrome. Am J Hematol 2020; 95: E192-E194. doi: 10.1002/ajh.25855.doi:10.1002/ajh.25855.

42 Rivera-Figueroa EI, Santos R, Simpson S, Garg P. Incomplete Kawasaki Disease in a Child with Covid-19. Indian Pediatr 2020; 57: 680-681. doi: 10.1007/s13312-0201900-0.

43 Jones VG, Mills M, Suarez D, Hogan CA, Yeh D, Segal ; J Bradley et al. COVID-19 and Kawasaki Disease: Novel Virus and Novel Case. Hosp Pediatr. 2020;10:537-540. doi:10.1542/hpeds.2020-0123.

44 Balasubramanian S, Nagendran TM, Ramachandran B RA. Hyper-inflammatory Syndrome in a Child With COVID-19 Treated Successfully With Intravenous Immunoglobulin and Tocilizumab. Indian Pediatr 2020; 57: 681-683. doi: 10.1007/s13312-020-1901-z.

45 Ozdemir H, Ciftçi E, Tapisiz A, Ince E, Tutar E, Atalay S et al. Clinical and epidemiological characteristics of children with Kawasaki disease in Turkey. J Trop Pediatr 2010; 56: 260ї 262. doi: 10.1093/tropej/fmp110.

46 Fukushige J, Takahashi N, Ueda Y, Ueda K. Incidence and clinical features of incomplete Kawasaki disease. Acta Paediatr 1994; 83: 1057ї 1060. doi: 10.1111/j.1651-2227.1994.tb12985.x.

47 Sung RYT, Ng YM, Choi KC, Mok GCF, Cheng YW, Ho MHK. Lack of association of cervical lymphadenopathy and coronary artery complications in Kawasaki disease. Pediatr Infect Dis J 2006; 25: 521ї 525. doi: 10.1097/01.inf.0000215263.96289.1c.

48 Germain BF, Moroney JD, Guggino GS, Cimino L, Rodriguez C, Bocanegra TS. Anterior uveitis in Kawasaki disease. J Pediatr 1980; 97: 780ї 781. doi: 10.1016/s0022-3476(80)80267-8.

49 Baker AL, Lu M, Minich LLA, Atz AM, Klein GL, Korsin R et al. Associated 
medRxiv preprint doi: https://doi.org/10.1101/2021.04.23.21255879; this version posted April 25, 2021. The copyright holder for this preprint (which was not certified by peer review) is the author/funder, who has granted medRxiv a license to display the preprint in perpetuity. All rights reserved. No reuse allowed without permission.

\section{MIS-C and COVID-19}

Symptoms in the Ten Days Before Diagnosis of Kawasaki Disease. J Pediatr 2009; 154: 592-595. doi:10.1016/j.jpeds.2008.10.006.

Dominguez SR, Anderson MS, El-Adawy M, Glodé MP. Preventing coronary artery abnormalities: A need for earlier diagnosis and treatment of Kawasaki disease. Pediatr Infect Dis J 2012; 31: 1217ї 1220. doi: 10.1097/INF.0b013e318266bcf9.

51 Printz BF, Sleeper LA, Newburger JW, Minich LL, Bradley T, Cohen MS et al. Noncoronary cardiac abnormalities are associated with coronary artery dilation and with laboratory inflammatory markers in acute kawasaki disease. J Am Coll Cardiol 2011; 57: 86ї 92. doi: 10.1016/j.jacc.2010.08.619.

52 Lahfaoui M, Azizi M, Elbakkaoui M, El Amrani R, Kamaoui I, Benhaddou H. Acute respiratory distress syndrome secondary to SARS-CoV-2 infection in an infant. Rev Mal Respir 2020; 37: 502ї 504. doi: 10.1016/j.rmr.2020.04.009.

53 Licciardi F, Pruccoli G, Denina M, Parodi E, Taglietto M, Rosati S et al. SARS-CoV2-Induced Kawasaki-Like Hyperinflammatory Syndrome: A Novel COVID Phenotype in Children. Pediatrics 2020; 146: e20201711. doi: 10.1542/peds.2020-1711.

54 Gefen AM, Palumbo N, Nathan SK, Singer PS, Castellanos-Reyes LJ, Sethna CB. Pediatric COVID-19-associated rhabdomyolysis: a case report. Pediatr Nephrol 2020; 35:1517-1520. doi: 10.1007/s00467-020-04617-0.

55 Swann O V, Holden KA, Turtle L, Pollock L, Fairfield CJ, Drake TM et al. Clinical characteristics of children and young people admitted to hospital with covid-19 in United Kingdom: prospective multicentre observational cohort study. BMJ 2020; 370: m3249. doi: 10.1136/bmj.m3249.

56 Feldstein LR, Tenforde MW, Friedman KG, Newhams M, Rose EB, Dapul H et al. Characteristics and Outcomes of US Children and Adolescents with Multisystem Inflammatory Syndrome in Children (MIS-C) Compared with Severe Acute COVID19. JAMA 2021; 325: 1074ї 1087. doi: 10.1001/jama.2021.2091.

57 Godfred-Cato S, Bryant B, Leung J, Oster ME, Conklin L, Abrams J et al. COVID19 Ï Associated Multisystem Inflammatory Syndrome in Children--United States, Marchï July 2020. MMWR Morb Mortal Wkly Rep 2020; 69: 1074ї 1080. doi: 10.15585/mmwr.mm6932e2.

58 Rostad CA, Chahroudi A, Mantus G, Lapp SA, Teherani M, Macoy L et al. Quantitative SARS-CoV-2 Serology in Children With Multisystem Inflammatory Syndrome (MIS-C). Pediatrics 2020; 146: e2020018242. doi: 10.1542/peds.2020018242. 